\title{
ANALISIS KOMITMEN ORGANISASI, IKLIM ORGANISASI DAN KEPUASAN KERJA PEGAWAI DI SEKRETARIAT JENDERAL KEMENTERIAN AGAMA RI
}

\author{
Eko Sugiyanto \\ Fakultas Ilmu Sosial dan Ilmu Politik, Universitas Nasional Jakarta \\ ekoantodr@gmail.com
}

\begin{abstract}
ABSTRAK
Penelitian ini dilatar-belakangi pentingnya penciptaan kepuasan kerja pegawai dalam organisasi sebagai upaya pemeliharaan pegawai. Kepuasan kerja pegawai erat kaitannya dengan komitmen dan iklim organisasi. Dalam dunia kerja, komitmen organisasi acapkali menjadi isu penting, bahkan ada beberapa organisasi publik dan/atau bisnis yang berani memasukkan faktor komitmen organisasi sebagai syarat spesifikasi jabatan (job specification) dalam satuan organisasi yang ditawarkan pihak manajemen, begitupun dengan faktor iklim organisasi. Mengacu hasil penelitian pendahuluan yang dilakukan di Sekretariat Jenderal Kementerian Agama RI, terdapat masalah yang diduga memiliki hubungan sebab akibat antara komitmen organisasi, iklim organisasi dan kepuasan kerja pegawai. Dengan menggunakan pendekatan kuantitatif, hasilnya menunjukkan bahwa meski komitmen organisasi, iklim organisasi masingmasing memiliki korelasi dan kontribusi positif serta signifikan terhadap kepuasan kerja pegawai, tetapi ada perbedaan yang signifikan pada korelasi dan kontribusinya, di mana iklim organisasi mempunyai pengaruh dan kontribusi yang lebih tinggi ketimbang komitmen organisasi. Dengan demikian faktor penyebab yang paling dominan mempengaruhi kepuasan kerja pegawai di Sekretariat Jenderal Kementerian Agama RI adalah iklim organisasi.
\end{abstract}

Kata kunci : Komitmen Organisasi, Iklim Organisasi, dan Kepuasan Kerja Pegawai. 


\begin{abstract}
Job satisfaction in an organization plays an important part in employees' performance. It has connection with commitment and work atmosphere in the organization. With referrence to the previous study on the issue within office of the Secretariat General of the Ministry of Religious Affairs of the Republic of Indonesia, there seem to exist problems in the issue. The paper further makes an account of job satisfaction in the organization. Using quantitative method, the finding of the study is that work atmosphere plays more significant part in maintaining job satisfaction among the employees of the Secretariat General of the Ministry of Religious Affairs than that contributed by commitment.
\end{abstract}

Keywords : Organization's commitment, work atmosphere, employees' job satisfaction

\title{
1. PENDAHULUAN
}

Kementerian Agama adalah institusi negara yang bertugas membantu Presiden dalam menyelenggarakan pemerintahan negara dalam urusan bidang keagamaan. Mengingat cakupan wilawah dan lingkup tugasnya amat luas, maka susunan organisasi dalam Kementerian Agama menurut Pasal 4 Peraturan Menteri Agama Republik Indonesia (RI) Nomor 10 Tahun 2010 tentang Organisasi dan Tata Kerja terdiri atas 10 (sepuluh) unit kerja, salah satunya adalah Sekretariat Jenderal.

Sekretariat Jenderal merupakan unsur pembantu pimpinan yang berada di bawah dan bertanggung jawab kepada Menteri Agama, dipimpin oleh Sekretaris Jenderal yang mempunyai tugas melaksanakan koordinasi pelaksanaan tugas, pembinaan dan pemberian dukungan administrasi kepada seluruh unit organisasi di lingkungan Kementerian Agama. Dalam melaksanakan tugasnya, Sekretariat Jenderal menyelenggarakan fungsi: (a). koordinasi kegiatan Kementerian Agama; (b). koordinasi dan penyusunan rencana dan program Kementerian Agama; (c). pembinaan dan pemberian dukungan administrasi yang meliputi ketatausahaan, kepegawaian, keuangan, kerumahtanggaan, arsip dan dokumentasi Kementerian Agama; (d). pembinaan dan penyelenggaraan organisasi dan tata laksana, kerja sama, dan hubungan masyarakat; (e). koordinasi dan penyusunan peraturan perundangundangan dan bantuan hukum; (f). penyelenggaraan pengelolaan barang milik/kekayaan negara; (g). pelaksanaan tugas lain yang diberikan oleh Menteri Agama. Susunan organisasi Sekretariat Jenderal menurut pasal 8 
Peraturan Menteri Agama RI Nomor 10 Tahun 2010, terdiri atas 7 (tujuh) biro dengan jumlah pegawai sekitar 50-150 orang setiap bironya.

Sebagai upaya mewujudkan tata kelola pemerintahan yang baik (goodgovernance) searah dengan kebijakan reformasi nasional, saat ini Kementerian Agama tengah melaksanakan program reformasi birokrasi yang fokusnya pada perbaikan bidang kelembagaan, ketatalaksanaan, dan kepegawaian. Perbaikan bidang kelembagaan terkait dengan pelaksanaan penataan organisasi agar lebih efisien dan efektif dalam mentransformasikan dan merefleksikan setiap tugas dan fungsinya. Lalu secara simultan dilakukan pula perbaikan bidang ketatalaksanaan dan kepegawaian yang produknya berupa uraian jabatan (job description), dan produk ini kemudian dijadikan dasar untuk lakukan berbagai kegiatan manajemen kepegawaian, di antaranya menyusun persyaratan spesifikasi jabatan (job specification), peta jabatan (job map), dan peringkat jabatan (job grading). Dari sini diharap akan dapat mendukung dan memperlancar pelaksanaan program reformasi birokrasi bidang kepegawaian, yaitu melaksanakan manajemen kepegawaian yang mampu menentukan kebutuhan pegawai secara kuantitas maupun kualitas, tepat dan proporsional pada setiap unit organisasi.

Belakangan ini komitmen organisasi acapkali jadi isu penting sehingga beberapa organisasi publik dan/atau bisnis berani memasukkan faktor komitmen organisasi sebagai salah satu persyaratan spesifikasi jabatan (job specification) dalam satuan organisasi. Meski hal ini bukan lagi rahasia umum, namun tidak jarang pihak manajemen dan/atau pegawai masih belum memahami makna komitmen secara serius. Komitmen itu tidak sekedar kesediaan pegawai menetap di organisasi dalam jangka waktu lama, namun juga mereka secara optimal mengeluarkan potensi diri dan mau memberikan yang terbaik kepada organisasi, bahkan bersedia mengerjakan sesuatu melampaui batas yang diwajibkan. Dengan memasukkan faktor komitmen organisasi kedalam persyaratan jabatan, diharap pegawai merasa terpuaskan atau mendorong tercapainya kepuasan kerja. Begitupun dengan faktor iklim organisasi, diharap pegawai merasa diberi tanggung jawab untuk melaksanakan pekerjaan demi tercapainya tujuan organisasi sehinga dapat mengambil keputusan dan memecahkan persoalan penting bagi organisasi.

Mengacu hasil penelitian pendahuluan di Sekretariat Jenderal Kementerian Agama RI, diketahui bahwa komitmen pegawai sesungguhnya relatif positif karena ada pertanda bahwa pegawai menetap dalam suatu organisasi atas keinginan sendiri, selain merasa wajib loyal pada organisasi. Begitupun dengan iklim organisasi, pegawai merasa diberi tanggung jawab untuk melaksanakan pekerjaan demi pencapaian tujuan organisasi. Hanya saja, faktor komitmen pegawai dan iklim organisasi ini belum berbanding lurus dengan tingkat kepuasan kerja pegawai, karena promosi sebagai anak tangga untuk meningkatkan karir selama pegawai bekerja di organisasi 
tersebut dinilai belum berjalan secara terbuka. Fenomena yang teridentifikasi sebagai komitmen organisasi, iklim organisasi dan kepuasan kerja pegawai sedemikian inilah yang kemudian mendorong pengajian lebih lanjut tentang seberapa besar pengaruh komitmen organisasi dan iklim organisasi terhadap kepuasan kerja pegawai di Sekretariat Jenderal Kementerian Agama RI.

\section{METODE STUDI}

Penelitian ini dikembangkan melalui studi kasus dengan pendekatan kuantitatif yang mengikuti paradigma positivisme yang bersifat logicohypotheco-verifikatif dan mempertimbangkan kaidah dasar dari probability sampling secara acak (random sampling). Selain menyebarkan kuesioner, dilakukan juga observasi lapangan serta telaah dokumentasi media cetak, elektronik maupun online guna menambah acuan analisis dan interpretasi peneliti. Sedangkan dari segi teknik, pengumpulan data dilakukan dengan memanfaatkan teknik observation (pengamatan), interview (wawancara), dan dokumentasi. Untuk memeriksa keabsahan datanya, digunakan teknik triangulasi atau membandingkan data yang diperoleh dari satu sumber dengan menggunakan metode yang berbeda.

\section{KERANGKA KONSEPTUAL}

\subsection{Komitmen Organisasi}

Sebuah model terjadinya hasil komitmen organisasi terutama jika dikaitkan dengan capaian tujuan organisasi, menurut Steers (1998: 89) ada 3 (tiga) faktor:

1). Ciri pribadi pekerja, termasuk masa jabatan dalam organisasi dan variasi kekuatannya kebutuhannya;

2). Ciri pekerjaannya, seperti identitas tugas dan kesempatan berinteraksi dengan rekan sekerja;

3). Pengalaman kerja, seperti keterhandalan dalam organisasi yang terlihat di masa lampau dan cara pekerja-pekerja lainnya memperbincangkan dan mengutarakan perasaan mereka mengenai organisasi.

Sekalipun Steers tidak secara tegas mengatakan komitmen berpengaruh terhadap kepuasan kerja, tetapi dalam situasi hubungan pekerja dan organisasi yang begitu kompleks, beberapa aspek kepuasan kerja dapat dipenuhi melalui manifestasi komitmen organisasi. Model hubungan sebab akibat komitmen organisasi yang bersifat lingkaran umpan balik ini pada situasi tertentu dapat menjelaskan hubungan antara komitmen organisasi dan kepuasan kerja. 
Dalam konteks ini dikatakan Sudarmanto (2009:102) bahwa komitmen organisasi terkait dengan kekuatan identifikasi individu dan keterlibatannya dalam organisasi tertentu. Sementara Robbins (1998:66) menganggap komitmen organisasi merupakan keadaan dimana seorang karyawan memihak pada suatu organisasi tertentu dan tujuan-tujuan organisasi serta berniat memelihara keanggotaan dalam organisasi tersebut. Lebih lanjut dikatakan Allan \& Meyer (Sudarmanto, 2009:102), ada 3 (tiga) bentuk komitmen organisasi yaitu:

1). Komitmen afektif, merupakan komitmen yang menimbulkan perasaan memiliki dan terlibat dalam organisasi;

2). Komitmen kontinuan, merupakan komitmen atas biaya atau risiko yang harus ditanggung apabila seseorang keluar dari organisasi;

3). Komitmen normatif, merupakan komitmen yang menimbulkan keinginan/perasaan karyawan untuk tetap tinggal di sebuah organisasi.

Komitmen afektif dapat berupa keikatan emosional identifikasi dan keterlibatan dalam suatu organisasi. Artinya, pegawai menetap dalam suatu organisasi karena keinginan sendiri. Komitmen kontinuan, yaitu komitmen pegawai yang didasarkan pada pertimbangan tentang apa yang harus dikorbankan bila akan meninggalkan organisasi. Dalam hal ini pegawai memutuskan menetap pada suatu organisasi karena menganggapnya sebagai suatu pemenuhan kebutuhan. Komitmen normatif, yaitu keyakinan pegawai tentang tanggung jawab terhadap organisasi. Pegawai tetap tinggal pada suatu organisasi karena merasa wajib untuk loyal pada organisasi tersebut.

Beberapa peneliti memilih dimensi komitmen organisasi dari Allan dan Meyer sebagai alat ukur, dengan anggapan model tersebut lebih menampilkan secara jelas komitmen organisasi itu sendiri, dimana dimensi komitmen kohesi pada prinsipnya mirip dengan komitmen kendali, sementara kedua komitmen tersebut belum menunjukkan gambaran tingkat komitmen seseorang. Misalnya, seseorang yang bekerja pada suatu organisasi umumnya bertujuan sekedar pemenuhan kebutuhan dan jika peluang kerja lain ada dan lebih berarti bagi dia, maka mungkin saja dia akan meninggalkan organisasi tersebut. Karenanya, dalam kajian ini dimensi yang digunakan untuk mengukur komitmen organisasi mengacu pada pendapatnya Allan \& Meyer, yaitu: Komitmen afektif; Komitmen kontinuan; dan Komitmen normatif.

\subsection{Iklim Organisasi}

Istilah iklim organisasi (organization climate) pertama kalinya dipakai oleh Kurt Lewin, yang sebelumnya menggunakan iklim 
psikologi. Lalu diteruskan Tagiuri dan Litwin (Sobirin, 2007:144), bahwa iklim organisasi merupakan kualitas lingkungan internal organisasi yang dirasakan dan dialami oleh para anggota organisasi, yang mempengaruhi perilaku mereka, dan yang bisa dijelaskan dalam bentuk satu set karakteristik atau atribut organisasi. Wirawan (2008:122) menganggap, iklim organisasi adalah persepsi anggota organisasi (secara individual dan kelompok) dan mereka yang secara tetap berhubungan dengan organisasi mengenai apa yang ada atau terjadi di lingkungan internal organisasi secara rutin, yang mempengaruhi sikap dan perilaku organisasi dan kinerja anggota organisasi yang kemudian menentukan kinerja organisasi. Sedangkan iklim organisasi menurut Davis \& Newstrom (1981:22) menunjuk cara hidup suatu organisasi. Iklim dapat menimbulkan pengaruh besar terhadap kepuasan kerja pegawai. Iklim mempengaruhi hal itu dengan tindakan yang harapan pegawai ada konsekuensi yang akan timbul dari berbagai tindakan yang mereka lakukan.

Terkait hal di atas, Sedarmayanti (2008:76) membagi dimensi iklim organisasi menjadi sebagai berikut:

1). Struktur pekerjaan, yakni tingkat aturan-aturan yang diberikan pada pegawai apakah ada penekanan dari atasan terhadap mereka;

2). Tanggung jawab, yakni berhubungan dengan memotivasi pegawai untuk membuat keputusan yang meliputi elemen penting dari desentralisasi untuk melakanakan pekerjaan;

3). Kesediaan menerima resiko, artinya pegawai dalam mengambil keputusan harus dapat memikirkan kemungkinan timbulnya resiko akibat keputusan yang diambil;

4). Kehangatan, yakni pegawai dapat merasakan suasana yang hangat dalam organisasi;

5). Dukungan, yaitu pegawai dapat merasakan kepentingan mereka mendapat dukungan;

6). Standar kinerja, yaitu penetapan kualitas dan kuantitas produk yang diharapkan organisasi pada pegawainya;

7). Konflik, yaitu pertentangan yang muncul diantara sebagian pegawai;

8). Identitas, yakni kesediaan pegawai pada kelompoknya.

Sedangkan Kolb, dkk (Wirawan, 2002:131) memberikan 7 (tujuh) dimensi yang merupakan modifikasi dari Litwin dan Stringer, yaitu:

1). Konformitas, yaitu seberapa banyak batasan yang dikenakan di dalam organisasi secara eksternal;

2). Tanggung jawab, yaitu pegawai merasa bahwa mereka diberi tanggung jawab untuk melaksanakan pekerjaan demi tujuan organisasi dan dapat mengambil keputusan dan memecahkan persoalan; 
3). Standar pelaksanaan pekerjaan, yaitu bagaimana organisasi menetapkan tujuan yang menantang dan mengutamakan kualitas pekerjaan dan produksi;

4). Imbalan, yaitu pegawai merasa dihargai, mendapat imbalan dengan baik, tidak hanya dikritik dan diabaikan jika melakukan sesuatu yang salah;

5). Kejelasan organisasi, yaitu pegawai merasa bahwa segala sesuatunya diorganisir dengan baik, tujuan organisasi dirumuskan dengan jelas dan tidak membingungkan;

6). Hubungan interpersonal dan semangat kelompok, yaitu pegawai saling mempercayai, saling membantu dan adanya hubungan baik antar pegawai di dalam lingkungan organisasi;

7). Kepemimpinan, yaitu sejauhmana kepemimpinan yang ada di dalam organisasi diterima atau ditolak pegawainya.

Dalam pada itu Stringe (Wirawan, 2002:131), berpendapat bahwa karakteristik atau dimensi iklim organisasi mempengaruhi motivasi anggota organisasi untuk berperilaku tertentu. Oleh karena itu, iklim organisasi dapat dilukiskan dan diukur dalam pengertian dimensi tersebut. Lebih lanjut dikatakan bahwa untuk mengukur iklim organisasi terdapat 6 (enam) dimensi yang diperlukan, yaitu:

1). Struktur. Struktur organisasi merefleksikan perasaan di organisasi secara baik dan mempunyai peran dan tanggung jawab yang jelas dalam lingkungan organisasi. Struktur tinggi jika anggota organisasi merasa pekerjaan mereka didefinisikan secara baik. Struktur rendah jika mereka merasa tidak ada kejelasan mengenai siapa yang melakukan tugas dan mempunyai kewenangan mengambil keputusan;

2). Standar-standar. Standar-standar dalam suatu organisasi mengukur perasaan tekanan untuk meningkatkan kinerja dan derajat kebanggaan yang dimiliki oleh anggota organisasi dalam melakukan pekerjaan dengan baik. Standar-standar tinggi artinya anggota organisasi selalu berupaya mencari jalan untuk mening-katkan kinerja. Standar-standar rendah merefleksikan harapan yang lebih rendah untuk kinerja;

3). Tanggung jawab. Tanggung jawab merefleksikan perasaan karyawan bahwa mereka menjadi "bos diri sendiri" dan tidak memerlukan keputusannya dilegitimasi oleh anggota organisasi lainnya. Persepsi tanggung jawab tinggi menunjukkan bahwa anggota organisasi merasa didorong untuk memecahkan problemnya sendiri. Tanggung jawab rendah menunjukkan bahwa pengambilan risiko dan percobaan terhadap pendekatan baru tidak diharapkan; 
4). Penghargaan/pengakuan. Penghargaan mengindikasikan bahwa anggota organisasi merasa dihargai jika mereka dapat menyelesaikan tugas secara baik. Penghargaan merupakan ukuran penghargaan dihadapkan dengan kritik dan hukuman atas penyelesaian pekerjaan. Iklim organisasi yang menghargai kinerja berkarakteristik keseimbangan antara imbalan dan kritik. Penghargaan rendah artinya penyelesaian pekerjaan dengan baik diberi imbalan secara tidak konsisten;

5). Dukungan. Dukungan merefleksikan perasaan percaya dan saling mendukung yang terus berlangsung di antara anggota kelompok kerja. Dukungan tinggi jika anggota organisasi merasa bahwa mereka bagian tim yang berfungsi dengan baik dan merasa memperoleh bantuan dari atasannya, jika mengalami kesulitan dalam menjalankan tugas. Jika dukungan rendah, anggota organisasi merasa terisolasi atau tersisih sendiri. Dimensi iklim organisasi menjadi penting untuk model bisnis yang ada, di mana sumber-sumber sangat terbatas;

6). Komitmen. Komitmen merefleksikan perasaan bangga anggota terhadap organisasinya dan derajat keloyalan terhadap pencapaian tujuan organisasi. Perasaan komitmen kuat berasosiasi dengan loyalitas personal. Level rendah komitmen artinya karyawan merasa apatis terhadap organisasi dan tujuannya.

Dimensi yang digunakan untuk mengukur iklim organisasi dalam kajian ini meliputi: Struktur pekerjaan/konformitas; Tanggung jawab; dan Penghargaan/pengakuan. Struktur pekerjaan/konformitas, yakni tingkat aturan-aturan yang diberikan pada pegawai apakah ada penekanan dari atasan terhadap mereka. Struktur organisasi merefleksikan perasaan secara baik dan mempunyai peran dan tanggung jawab yang jelas dalam lingkungan organisasi. Struktur tinggi jika anggota organisasi merasa pekerjaan mereka didefinisikan secara baik. Struktur rendah jika mereka merasa tidak ada kejelasan mengenai siapa yang melakukan tugas dan mempunyai kewenangan mengambil keputusan. Tanggung jawab berhubungan dengan memotivasi pegawai untuk membuat keputusan yang meliputi elemen penting dari desentralisasi untuk melakanakan pekerjaan. Tanggung jawab berarti pegawai merasa diberi tanggung jawab untuk melaksanakan pekerjaan demi tujuan organisasi dan dapat mengambil keputusan maupun memecahkan persoalan. Penghargaan/pengakuan mengindikasikan bahwa anggota organisasi merasa dihargai jika mereka dapat menyelesaikan tugas secara baik.. Penghargaan rendah artinya jika penyelesaian pekerjaan dengan baik, namun diberi imbalan secara tidak konsisten. 


\subsection{Kepuasan Kerja Pegawai}

Teori kepuasan kerja pada umumnya berhubungan erat dengan teori motivasi, karenanya Kreiner dan Kenichi (1992:119) membagi teori penentu kepuasan kerja meliputi:

1). Teori pemenuhan kebutuhan (need fullfilment), yakni makin banyak kebutuhan-kebutuhan yang terpenuhi oleh lingkungan pekerjaan maka makin tinggi derajat kepuasan kerjanya;

2). Teori kesenjangan (discrepancies), menyatakan bahwa kepuasan kerja seseorang bergantung pada kesenjangan antara apa yang seharusnya (harapan, kebutuhan atau nilai) dengan apa yang menurut perasaannya telah diperoleh melalui pekerjaannya;

3). Teori pencapaian nilai (vallue attainment), yaitu mirip dengan teori kesenjangan, akan tetapi yang menjadi titik sentral adalah nilai atau value yang dianut individunya;

4). Teori kesamaan (equity), dimana kepuasan dilihat dari perbandingan antara dirinya dengan rekan sekerja;

5). Teori komponen genetik (genetic component), menyatakan bahwa sebagian kepuasan kerja merupakan fungsi dari genetik.

Konsep kepuasan kerja mempunyai definisi yang variatif, tetapi pada prinsipnya mempunyai pandangan yang sama sebagai respon emosional dan afeksi. Sebagaimana dijelaskan Siegel dan Lane (Robbins, 1998: 125) misalnya, kepuasan kerja adalah cara seseorang merasakan pekerjaannya. Kepuasan kerja merupakan generalisasi sikap pekerja terhadap pekerjaannya yang memiliki berbagai aspek. Sikap seseorang terhadap pekerjaannya mencerminkan pengalaman yang menyenangkan atau tidak menyenangkan dalam pekerjaannya serta harapan-harapannya di masa depan. Sedangkan Davis (1992: 12) menganggap bahwa kepuasan kerja adalah seperangkat perasaan pegawai tentang menyenangkan atau tidak menyenangkannya pekerjaan mereka. Begitupun dengan Rivai (2005: 475), bahwa kepuasan kerja merupakan evaluasi yang menggambarkan seseorang atas perasaan sikap senang atau tidak senang, puas atau tidak puas dalam bekerja.

Bagi Robbins (1998:16), kepuasan kerja adalah sebagai suatu sikap umum seorang individu terhadap pekerjaannya. Sementara Porter (Robbins, 1998:43) menganggap kepuasan kerja merupakan selisih dari sesuatu yang seharusnya ada (harapan) dengan yang sesungguhnya (kenyataan). Kepuasan kerja pegawai merupakan keadaan emosional yang menyenangkan atau tidak menyenangkan dalam mana para pegawai memandang pekerjaan mereka. Kepuasan kerja pegawai mencerminkan perasaan seorang pegawai terhadap pekerjaannya. Hal ini nampak dalam sikap positif pegawai terhadap pekerjaan dan segala sesuatu yang 
dihadapi di lingkungan kerjanya. Organisasi harus senantiasa memonitor kepuasan kerja pegawai, karena hal itu mempengaruhi tingkat absensi, perputaran pegawai, semangat kerja pegawai, keluhan-keluhan dan masalah-masalah personalia vital lainnya. Karenanya, Locke (Robbins, 1998: 39) membagi sembilan dimensi kerja yang merupakan pengembangan dari Locke sebelumnya dan mempunyai kontribusi terhadap kepuasan kerja yaitu:

1). Pekerjaan, termasuk minat intrinsik, variasi tugas, kesempatan belajar, kesulitan kerja, jumlah kerja, kesempatan untuk berhasil, kontrol terhadap langkah-langkah pekerjaan dan metode pekerjaan;

2). Pembayaran, termasuk jumlah pembayaran, keadilan pembayaran dan cara pembayarannya;

3). Promosi, termasuk keadilan mendapatkan promosi dan kesempatan mendapat promosi;

4). Pengakuan, termasuk penghargaan terhadap prestasi, kepercayaan atas tugas yang diberikan dan kritik-kritik atas tugas yang dikerjakan;

5). Benefit, termasuk memperoleh pensiun, mendapat kesehatan, adanya cuti tahunan dan adanya pembayaran pada saat liburan.

6). Kondisi kerja, termasuk jam kerja, jam istirahat, peralatan kerja, temperatur di lokasi kerja, ventilasi, kelembaban, lokasi dan tata ruang kerja;

7). Supervisi, termasuk gaya dan pengaruh supervisi, hubungan manusia dan ketrampilan administratif;

8). Rekan kerja, termasuk kompetensi, saling membantu dan keramahan antar rekan kerja;

9). Organisasi dan manajemen (Kebijakan oganisasi), termasuk kebijakan akan perhatian terhadap pekerja, baik untuk pembayaran ataupun benefit-benefit.

Dimensi yang digunakan untuk mengukur kepuasan kerja pegawai dalam konteks penelitian ini mempertimbangkan pendapat Locke (Robbins: 1998), terutama terkait: Pekerjaan; Promosi; Rekan kerja; dan Organisasi dan manajemen (Kebijakan oganisasi). Pegawai cenderung menyukai pekerjaan yang memberikan kesempatan untuk memanfaatkan ketrampilan dan kemampuan mereka dan menawarkan keanekaragaman tugas, kebebasan dan umpan balik tentang sejauhmana baiknya pekerjaan yang mereka lakukan. Pekerjaan yang kurang menantang menciptakan kebosanan, namun terlalu banyak tantangan malah dapat menciptakan frustasi dan perasaan gagal. Pegawai berhak mendambakan dan mendapatkan promosi, sebagai 
anak tangga untuk meningkatkan karir selama pegawai bekerja di organisasi tersebut sesuai prestasi kerjanya. Rekan kerja yang mendukung merupakan salah satu bagian yang tidak terpisahkan dalam melakukan pekerjaan juga sekaligus memenuhi kebutuhan mereka terhadap interaksi sosial. Pegawai lebih puas bila mempunyai rekan kerja yang menyenangkan, saling mendukung mempunyai supervisor yang penuh perhatian, bersahabat, menghargai hasil kerja, mendengarkan pendapat pegawai dan menunjukkan minat pribadi terhadap bawahannya. Organisasi dan manajemen (Kebijakan organisasi), termasuk kebijakan akan perhatian terhadap pekerja, baik untuk pembayaran ataupun benefit-benefit termasuk memperoleh pensiun, mendapat kesehatan, adanya cuti tahunan dan kondisi kerja (termasuk jam kerja, jam istirahat, peralatan kerja, temperatur di lokasi kerja, ventilasi, kelembaban, lokasi dan tata ruang kerja) serta penghargaan terhadap prestasi.

\section{KARAKTERISTIK KOMITMEN ORGANISASI, IKLIM ORGANISASI DAN KEPUASAN KERJA PEGAWAI}

\subsection{Komitmen Organisasi}

Komitmen organisasi merupakan kompetensi pegawai dalam mengikatkan dirinya terhadap nilai dan tujuan organisasi. Keterikatan ini akan mendorong individu untuk menyelaraskan dirinya dengan tujuan dan kepentingan organisasi, sehingga tercipta loyalitas yang kuat terhadap organisasi. Komitmen organisasi merupakan hubungan pegawai dengan organisasinya, dimana seorang pegawai dengan komitmen kerja yang tinggi akan memperlihatkan keinginan kuat untuk menjadi anggota organisasi, berusaha sebaik mungkin, serta memiliki penerimaan yang kuat terhadap nilai-nilai dan tujuan organisasi. Karakteristik komitmen organisasi dimaksud meliputi:

1). Afektif/keikatan emosional;

2). Kontinuan/risiko;

3). Normatif/loyalitas.

\subsection{Iklim Organisasi}

Iklim organisasi fokus pada persepsi-persepsi yang masuk akal atau dapat dinilai, terutama yang memunculkan motivasi, sehingga mempunyai pengaruh langsung terhadap kinerja organisasi. Iklim organisasi secara objektif terjadi di setiap organisasi, dan mempengaruhi perilaku anggota organisasi. Karakteristik iklim organisasi dalam kajian ini meliputi: 
1). Struktur pekerjaan;

2). Tanggung jawab;

3). Penghargaan/pengakuan.

\subsection{Kepuasan Kerja Pegawai}

Kepuasan kerja pegawai menyangkut sikap dan penilaian positif atau negatif seorang pegawai atas hasil pekerjaannya dan merupakan selisih dari sesuatu yang seharusnya ada (harapan) dengan yang sesungguhnya ada (kenyataan). Orang yang tidak terlibat dalam pekerjaan mereka tidak dapat diharapkan mendapatkan kepuasan kerja yang sama dengan mereka yang terlibat. Hal inilah yang menyebabkan dua orang pegawai dapat melaporkan tingkat kepuasan yang berbedabeda untuk tingkat hasil kerja yang sama. Perbedaan lain adalah keadilan yang dirasakan atas perolehan pegawai lain, jika perolehan itu dirasakan kurang adil maka pegawai akan merasa tidak puas dan berusaha mencari jalan untuk mendapatkan keadilan. Karena itu, karakteristik kepuasan kerja pegawai dalam kajian ini meliputi:
1). Pekerjaan;
2). Promosi;
3). Rekan kerja;
4). Organisasi dan manajemen (Kebijakan organisasi).

\section{HASIL PEMBAHASAN}

1. Komitmen organisasi secara umum dinilai baik, tetapi masih terdapat beberapa hal yang perlu diperhatikan yaitu: peningkatan yang lebih optimal tentang kebersamaan pegawai dalam melakukan tugas-tugas pekerjaan; kepatuhan pegawai terhadap peraturan yang berlaku; dukungan organisasi terhadap pelaksanaan kerja pegawai; dan rasa kebanggaan yang dimiliki pegawai terhadap organisasi;

2. Iklim organisasi secara umum dinilai baik, namun masih terdapat beberapa hal yang perlu diperhatikan yaitu: keseimbangan pelaksanaan kerja di bawah tekanan waktu/jam kerja; kejelasan batas-batas akan ruang lingkup tugas-tugas pekerjaan; kesesuaian produktivitas kerja pegawai terhadap strategi organisasi; kesesuaian pemberian insentif/bonus; kesesuaian pemberian fasilitas kesejahteraan lainnya kepada para pegawai; kesesuaian formalisasi/peraturan terhadap kesempatan pegawai untuk maju/berkembang; dan perhatian organisasi terhadap masa depan pegawai;

3. Kepuasan kerja pegawai secara umum dinilai baik, hanya saja terdapat beberapa hal yang perlu diperhatikan yaitu: pemberian kesempatan kepada pegawai untuk maju dan berkembang; pemberian motivasi maupun kesempatan promosi kepada setiap pegawai; pemberian 
penghargaan terhadap prestasi kerja yang dihasilkan pegawai; dan peran supervisi dalam penciptaan harmonisasi hubungan antar pegawai dalam pelaksanaan pekerjaan;

4. Komitmen organisasi berpengaruh kuat terhadap kepuasan kerja pegawai sebesar 0,622 dan signifikan pada taraf kepercayaan 95\%. Dengan model persamaan regresi linear sederhana: $\mathrm{Y}=19,466+0,541 \mathrm{X}_{1}$, jika setiap komitmen organisasi ditingkatkan sebanyak 1 unit, akan selalu terjadi selisih kenaikan kepuasan kerja pegawai sebanyak 0,541 unit. Besarnya variasi perubahan kepuasan kerja pegawai yang mampu dijelaskan oleh komitmen organisasi yang dimasukkan dalam model persamaan regresi sederhana serendah-rendahnya mencapai sekitar 37,10\%, sedangkan sisanya sebesar $62,90 \%$ dipengaruhi dari variabel bebas lain yang tidak dimasukkan ke dalam model persamaan regresi sederhana dan tidak diteliti. Dengan demikian komitmen organisasi mempunyai kontribusi kurang tinggi dalam menjelaskan kepuasan kerja pegawai;

5. Iklim organisasi berpengaruh sangat kuat terhadap kepuasan kerja pegawai sebesar 0,845 dan signifikan pada taraf kepercayaan $95 \%$. Dengan model persamaan regresi linear sederhana: $\mathrm{Y}=9,810+0,812 \mathrm{X}_{2}$, jika setiap iklim organisasi ditingkatkan sebanyak 1 unit, akan selalu terjadi selisih kenaikan kepuasan kerja pegawai sebanyak 0,812 unit. Besarnya variasi perubahan kepuasan kerja pegawai yang mampu dijelaskan oleh iklim organisasi yang dimasukkan dalam model persamaan regresi sederhana serendah-rendahnya mencapai sekitar $70,70 \%$, sedangkan sisanya sebesar $29,30 \%$ dipengaruhi dari variabel bebas lain yang tidak dimasukkan ke dalam model persamaan regresi sederhana dan tidak diteliti. Dengan demikian iklim organisasi mempunyai kontribusi tinggi dalam menjelaskan kepuasan kerja pegawai;

6. Komitmen dan iklim organisasi secara bersama-sama berpengaruh sangat kuat terhadap kepuasan kerja pegawai sebesar 0,888 dan signifikan pada taraf kepercayaan 95\%. Dengan model persamaan regresi linear ganda komitmen dan iklim organisasi secara bersama-sama terhadap kepuasan kerja pegawai adalah: $\mathrm{Y}=3,164+0,265 \mathrm{X}_{1}+0,681 \mathrm{X}_{2}$, jika setiap komitmen dan iklim organisasi secara bersama-sama ditingkatkan sebanyak 1 unit, akan selalu terjadi selisih kenaikan kepuasan kerja pegawai sebanyak 0,946 unit. Besarnya variasi perubahan kepuasan kerja pegawai yang mampu dijelaskan oleh komitmen dan iklim organisasi secara bersama-sama yang dimasukkan dalam model persamaan regresi ganda serendah-rendahnya mencapai sekitar $77,70 \%$, sedangkan sisanya sebesar 22,30\% dipengaruhi dari variabel bebas lain yang tidak dimasukkan ke dalam model persamaan regresi ganda dan tidak diteliti. Dengan demikian komitmen dan iklim organisasi secara bersama-sama mempunyai kontribusi tinggi dalam menjelaskan kepuasan kerja pegawai. 


\section{SIMPULAN}

Meski komitmen organisasi dan iklim organisasi masing-masing memiliki korelasi dan kontribusi positif serta signifikan terhadap kepuasan kerja pegawai, tetapi terdapat perbedaan yang signifikan pada korelasi dan kontribusinya terhadap kepuasan kerja pegawai, di mana iklim organisasi mempunyai pengaruh dan kontribusi yang lebih tinggi ketimbang komitmen organisasi. Dengan demikian dapat dijelaskan bahwa faktor penyebab yang paling dominan mempengaruhi kepuasan kerja pegawai di lingkungan Sekretariat Jenderal Kementerian Agama RI adalah iklim organisasi. 


\section{DAFTAR PUSTAKA}

Arikunto, Suharsimi. 2008. Prosedur Penelitian: Suatu Pendekatan Praktek. Jakarta: Rineka Cipta.

Davis, Keith, \& John W. Newstrom. 1981. Perilaku Dalam Organisasi. Jilid 1. Edisi Ketujuh. Jakarta: Erlangga.

Davis, Gordon B. 1992. Kerangka Dasar Sistem Informasi Manajemen. Jakarta: Pustaka Binaman Pressindo.

Ghozali, Iman. 2006. Aplikasi Analisis Multivariate dengan Program SPSS. Semarang: Badan Penerbit Universitas Diponegoro.

Hasibuan, Malayu S.P. 2001. Manajemen Sumber Daya Manusia: Dasar dan Kunci Keberhasilan. Jakarta: Haji Masagung.

Hersey, Paul Kenneth, H. Blanchard, Dewey E. Johnson. 1996. Management of Organizational Behaviour. Prentice Hall International, New Jersey.

Herskovits, Melville. 1997. Organization Theory. New York: Oxford University Press.

Kuncoro, Mudrajad. 2008. Metode Riset Untuk Bisnis \& Ekonomi. Jakarta: Erlangga.

Mescon, Albert dan Khedori. 1998. Dimensi Konstektual Dalam Kinerja. Jakarta: Bumi Aksara.

Rivai, Veithzal. 2005. Manajemen Sumber Daya Manusia Untuk Perusahaan: Dari Teori ke Praktik. Jakarta: Rajagrafindo Persada.

Robbins, Stephen P. 1998. Teori Organisasi, Struktur, Desain \& Aplikasi. Alih bahasa: Jusuf Udaya. Jakarta: Penerbit Arcan.

Sedarmayanti. 2008. Manajemen Sumber Daya Manusia: Reformasi Birokrasi dan Manajemen Pegawai Negeri Sipil. Bandung: Refika Aditama.

Sobirin, Achmad. 2007. Budaya Organisasi. Yogyakarta: STIM YKPN. 
Sugiyono. 2015. Metode Penelitian Administrasi. Bandung: Alfabeta.

Sedarmayanti. 2008. Manajemen Sumber Daya Manusia: Reformasi Birokrasi dan Manajemen Pegawai Negeri Sipil, Jakarta: PT. Refika Aditama.

Sudarmanto. 2009. Kinerja dan Pengembangan Kompetensi SDM. Yogyakarta: Pustaka Pelajar.

Steers, Richard M. 1998. Efektivitas Organisasi. Jakarta: Erlangga.

Wirawan. 2008. Budaya dan Iklim Organisasi. Jakarta: Salemba Empat. 